\title{
Evolution of a community-based, Scarlet Macaw conservation organization
}

\author{
Christopher Vaughan ${ }^{1,2,3}$ \\ 'Dept. of Wildlife Ecology, University of Wisconsin, Madison, WI 53706; cvaughan@wisc.edu \\ ${ }^{2}$ International Institute in Wildlife Conservation and Management, Universidad Nacional, Heredia, Costa Rica \\ ${ }^{3}$ Associated Colleges of the Midwest, San Jose, Costa Rica; cvaughan@acm.edu
}

Received 31-I-2012 Corrected 14-III-2012 Accepted 10-IV-2012

\begin{abstract}
This paper analyzed the evolution of a community-based effort to conserve the Central Pacific Scarlet Macaw (Ara macao) population in Costa Rica. Between 1990-1994, research demonstrated that the macaw population was declining, primarily due to chick poaching. Club Punta Leona, the town of Quebrada Ganado and the Universidad Nacional initiated the conservation efforts. Two regional workshops (1994, 1999) outlined and evaluated a protection strategy. Both workshops recommended: (a) carrying out strong environmental education programs, (b) protecting chicks in nests, (c) increasing macaw food and nesting sources, (d) research and monitoring of the macaw population, and (e) promoting the project and providing economic returns for local inhabitants. A local conservation organization, LAPPA, was created and attempted to carry out the strategy. Reviewing their successes, LAPPA's board of directors considered they had been effective with respect to items $\mathrm{a}, \mathrm{b}$ and $\mathrm{d}$. Strategic planning conducted at the workshops was essential for the conservation work. The methodology utilized in the second workshop helped outline the Scarlet Macaw workplan more clearly then the first. Finally, funds channelled through LAPPA for macaw conservation work have been utilized effectively. To ensure future success, board members believe that this program requires: (a) additional community leaders in more communities, (b) yearly strategic planning, (c) funding to hire a full-time staff member, (d) continued environmental education for children, (e) a transparent accounting system, and ( $f$ ) continued research and monitoring.
\end{abstract}

\section{KEY WORDS}

Ara macao, community-based conservation, Costa Rica, environmental education, monitoring, Scarlet Macaw, strategic planning.

\section{RESUMEN}

El estudio analiza la evolución de un esfuerzo comunitario para conservar la población de la lapa roja (Ara macao) del Pacifico Central de Costa Rica. Entre 1990-1994, investigación fue llevado a cabo para demostrar que la población estaba bajando, primordialmente debido a la explotación de los pichones. El Club Punta Leona, el Pueblo de Quebrada Ganado y la Universidad Nacional (Costa Rica) iniciaron un esfuerzo de conservación de la especie. Dos talleres regional fueron llevado a cabo en los años 1994 y 1999 para evaluar y detallar una estrategia de protección. Los dos talleres recomendaron: (a) llevar a cabo una programa de educación ambiental a nível local, (b) proteger los pichones en sus nidos, (c) aumentar las fuentes de alimentación y los sítios de anidar de las lapas, investigar y monitorear la población de lapa rojo constantemente y (d) promover el proyecto y proveer regresos económicos a los locales. Una organización local, LAPPA, se creo que para encargarse de llevar a cabo la estrategia. Revisando sus éxitos, la junta directiva de LAPPA considera que ellos han sido efectivos con respeto a puntos $\mathrm{a}$, b y d. La planificación estratégica llevado a cabo fue esencial para el trabajo de conservación. La metodología utilizado en el segundo taller ayudo a esquematizar el plan de trabajo para la lapa roja más claramente que el primer taller. Finalmente, los fondos canalizados a través de LAPPA para el trabajo de la conservación de la especie en forma exitosa. Para asegurar el éxito futuro, los miembros de las juntas consideran que el programa requiere: (a) lideres comunitarias adicionales, (b) planificación estratégica anual, (c) financiamiento para emplear un empleado tempo completo para LAPPA, (d) educación ambiental continua para escolares, (e) un sistema de contabilidad transparente, y (f) una continuación de las investigaciones y monitoreo de la población de lapa roja.

\section{PALABRAS CLAVE}

Ara macao, conservación a nivel de la comunidad, educación ambiental, monitoreo, lapa roja, planificación estratégica 


\section{Wildlands and wildlife conservation in the crucible}

Beginning in the 1970's, many developing countries followed the U.S. model of creating wildlands (national parks and equivalent reserves) by setting aside undisturbed habitats for the "enjoyment of current and future generations"(Ghai 1994). However, local politicians and residents increasingly questioned exclusion of locals from areas they had utilized for generations. Over $75 \%$ of wildlands in Latin America had ineffective protection, long-term management plans nor economic resources (World Conservation Monitoring Center 1992). Resentment, mistrust and conflicts often ensued between local communities and park officials (Boo 1990). Many leaders in developing countries labeled reserve creation a second wave of colonialism, and political pressure increased for radical changes in wildlands management (Kramer \& VanSchaik 1997).

Discussions at the international level focused on understanding the complex links between development, poverty and the environment resulting in the "sustainable development" concept. Following the 1992 United Nations Conference on Environment and Development (UNCED), a consensus emerged that rural "sustainable development" should be grounded in local-level solutions emanating from community initiatives (Ghai \& Vivian 1992, Ghai 1994). "Community-based conservation" promoted top-down, center-driven efforts to favor "natural resources or biodiversity protection by, for, and with the local community" (Western \& Wright 1994). Conservationists recognized long-term success depended on fostering cooperation and support of local communities (Western \& Wright 1994, Brandon et al. 1998, Agrawal \& Gibson 1999). However, most community-based conservation efforts fell short of expectations (Wells \& Brandon 1992, Wells 1994, Leach et al. 1999, Hulme \& Murphree 2001b).

\section{Community-based wildlife projects}

Excellent reviews of African, community-based wildlife conservation projects exist (Western \&Wright 1994, Hulme \& Murphree 2001a). These projects are naturally complex because they take into account multiple interests, actors and institutions that interact and influence decision-making (Agrawal \& Gibson 1999). Most conservation scientists have focused their efforts on the "high, hard ground" of species and ecosystem conservation (location, status, why important)(Salafsky et al. 2002). However, scientists have ignored the larger and more difficult "human" issues of conservation that reside in the "swampy lowlands". For instance, do local communities benefit from ecotourism in national parks (Vaughan 1999). According to Salafsky et al. (2002) several crucial questions remained: (a) what should conservation goals be, (b) how can we take action to achieve conservation, and (c) who are the people and groups that make conservation happen?

I had the opportunity to address the above questions while working with an endangered species in Costa Rica since the 1990's. This paper considered how strategic planning resulted in a Scarlet Macaw (Ara macao) conservation plan which was carried out by a conservation organization specifically set up for this purpose. I examined the what, how and who in tracing the evolution of Scarlet Macaw conservation project.

\section{Study site, human and Scarlet Macaw populations}

\section{Costa Rica, National Parks and social issues}

During the 1970's and 80's, Costa Rica created a worldclass wildlands system, consisting of $29 \%$ of the national territory $\left(14500 \mathrm{~km}^{2}\right)$ in 78 protected and private areas (Umaña \& Brandon 1992). However, by the early 1990s, the wildlands system and its biological riches were increasingly threatened by adjacent human communities. Facing similar wildland problems as those outlined above, Costa Rica also adopted a "sustainable development" approach and created the National System of Conservation Areas (SINAC) to manage its 78 wildlands and surrounding zones, as nine regional areas. This system promoted participation by all groups sharing the common objective of preservation, restoration, and protection of ecological equilibrium and biodiversity.

Eventually, SINAC wanted civil society and local communities to become responsible for management, concessions and research of wildlands while the state would be responsible only for facilitation and financing (Garcia 1993, Vaughan \& Rodriguez 1997). Although communitybased projects were promoted, usually with international funding, results to date have been mixed. These conservation projects are rare in Costa Rica, especially with wildlife species. A white-tailed deer (Odocoileus virginianus) reintroduction project at Cobano, Nicoyan Peninsula involving the local community functioned for $5 \mathrm{yrs}$ in the late 1980's (Hernandez 1993). The community of Ostional has been working for over a decade to manage the oliveridley sea turtle (Lepidochelys olivacea) with mixed results (Alvarado \& Ballestero 1995).

\section{Scarlet Macaw and Central Pacific Region}

In Costa Rica, the Scarlet Macaw originally occupied approximately $42500 \mathrm{~km}^{2}$ (85\% of national territory) (Vaughan 2011). Today, most of the population is found in three sites on the Pacific slope: (a) the Osa Peninsula 
(800-1200 estimated individuals)( Stiles \& Skutch 1989, Dear et al. 2011), (b) Palo Verde National Park (15 individuals) and (c) the Central Pacific (CP) region (327 individuals) (Marineros \& Vaughan 1995, Vaughan et al. 2005). Wildlands in the CP include: Carara National Park (5 500ha), Guacilillo Mangrove Reserve (1 100ha), Turrubares Protected Area (3 000ha) and Club Punta Leona (CPL) Private Biological Reserve (250ha).

In 1990, my assistants and I began ecological research on the CP Scarlet Macaw population. After several years, we determined that the population consisted of about 330 individuals living in a $560 \mathrm{~km}^{2}$ range of human-dominated landscape of cattle ranches, secondary forest, towns, primary forest and mangrove swamps (Marineros \&Vaughan 1995). About 10000 people inhabit the region, mostly in the towns of Tarcoles, Quebrada Ganado (QG), Herradura, Jaco, and Bijagual (Direccion General de Estadisticas y Censos 1987).

The principal economic activities of the region are ranching, tourism and fishing. Tourism employs up to $80 \%$ of the working class in some towns, such as Quebrada Ganado. The nearby resort of CPL is the major employer in the region, with 300 workers, mostly from Quebrada Ganado. Employment in tourism and small-scale fishing are major job sources in Tarcoles and Playa Azul, the poorest towns in the area. Agriculture occupies the working class in Bijagual. Tourists regularly visit beaches at Playas Blanca, Herradura, Jaco, Hermosa, Esterillos and Quepos (Vargas 1992).

\section{Macaw population decline, poaching, communites and Punta Leona}

After years of population monitoring, the Scarlet Macaw showed a six percent annual population decrease (Vaughan et al. 2005). Habitat loss was not a major factor, as secondary forests and exotic plantations of teak (Tectona grandis) and Gmelina arborea were increasing, replacing cattle ranches, and providing additional macaw food sources. Park guards and local residents suspected that chick poaching was causing population decline (Vaughan et al. 2005). For the estimated 10 poachers who lived in Tarcoles and Playa Azul, a macaw chick was worth between US\$300-400, equivalent to 2 months salary. Wildlife and park officials could not stop this illegal trade because of the difficulty of patrolling macaw nests randomly throughout their $560 \mathrm{~km}^{2}$ home range (Vaughan \& Liske 1991, Marineros \& Vaughan 1995). Local community and institutional support were needed to attack the poaching problem.

Interest in Scarlet Macaw conservation varied between and within communities in the region. Poachers from Tarcoles and Playa Azul, sold about 18 chicks yearly
(Marineros \& Vaughan 1995). Both towns were within a kilometer of Carara National Park and Guacilillo Mangrove Reserve, where many macaws nested, fed and roosted. In Bijagual and Quebrada Ganado, the other sizable towns, employment was greater and teachers and community leaders favored Scarlet Macaw conservation, relating it to tourism. This information was transmitted to children and townspeople. However, fewer macaws nested in these areas and only four known poachers lived in these two towns. In 1994, the declining macaw population interested and worried the two owners of $\mathrm{CPL}$, who wanted to increase the number of Scarlet Macaws in their resort. In mid-1994, CPL and the Universidad Nacional signed an agreement to collaborate on Scarlet Macaw conservation. The Universidad Nacional agreed to organize regional meetings to develop a strategy to conserve the Scarlet Macaw population. The rest of this paper explains the first two regional meetings carried out and the preliminar results, finalizing with lessons learned which can be applied to other conservation efforts involving endangered species and local human communities.

\section{METHODOLOGY}

\section{First regional workshop on Central Pacific Scarlet Macaw conservation}

\section{Organization}

We used the participative diagnostic planning process (see Nichter 1984 for examples) to devise a conservation strategy. Emilio Vargas, a rural sociologist from the Universidad Nacional, Heredia familiar with this methodology, was the facilitator. It consisted of four themes developed in sequential fashion: (a) discussing disorganized ideas about Scarlet Macaw conservation problems, (b) structuring ideas around the Scarlet Macaw problem, (c) analyzing causes and consequences of principal problems to conserve the species, and (d) formulating ideas to resolve principal problems. Two teams were formed to ensure active participation from all stakeholder groups. Priorities and expected results were set for specific objectives on the last afternoon.

Guillermo Hernández who represented the Quebrada Ganado community and the CPL and I organized the first workshop, carried out in the CPL in October 1994. The CPL provided an excellent work environment for the workshop (conference room, materials for writing on, lodging for university staff, and meals). During 2 days, 15 local stakeholders, including local community leaders from Quebrada Ganado and Tarcoles (5), national park staff (1), tourist resort managers, owners and employees (3), university 
professors (5), schoolteachers (1), macaw poachers (2) and businessmen (2) worked to design Scarlet Macaw conservation strategies. Marlene Leon was the only local woman present. Table 1 includes major stakeholders from the workshop and other macaw conservation activities.

\section{Second regional workshop on Central Pacific Scarlet Macaw conservation}

\section{Organization}

A methodology to design, manage and monitor conservation projects was used (Margoluis \& Salafsky 1998) as a basis for the workshop. The six-step process included: (a) clarify mission, (b) design conceptual model, (c) develop management plans, goals and objectives, (d) develop monitoring plan, (e) implementing management/monitoring plans and (f) analyzing data and communicating results to interested parties. The last two steps required project implementation, so were not included. I was the facilitator and my interventions were presenting a scientific overview of the project, assuring the methodology was followed and answering technical questions. This workshop was held November 3-4, 1999 and co-financed by CPL and the Wildlife Trust.

Only 12 of 40 invited participants from four communities attended due to a hurricane two days earlier. Seven of the 12 participants had attended the first workshop held five years earlier (Table 1). Among the new participants was Lisbeth Mora, director of the QG school and Roy Arroyo, naturalist for CPL who had recently moved to the region.

TABLE 1

Major stakeholders in Central Pacific Scarlet Macaw conservation, Costa Rica.

\begin{tabular}{|c|c|c|c|c|}
\hline Stakeholders & Occupation & Worksite & Participation & Main Conservation Role \\
\hline Enrique Andaniz & $\begin{array}{l}\text { Poacher/day } \\
\text { laborer }\end{array}$ & Villa Lapas & WSI & -informant on poaching techniques \\
\hline Roy Arroyo & Naturalist & Punta Leona & WSII, FMLII, BMLII & $\begin{array}{l}\text {-very bright \& dedicated } \\
\text {-leader of WSII } \\
\text {-President of IILAPPA }\end{array}$ \\
\hline Alvaro Bermudez & $\begin{array}{l}\text { Park } \\
\text { Subdirector }\end{array}$ & $\begin{array}{l}\text { Carara } \\
\text { Nat. Park }\end{array}$ & FMLII, BMLII & $\begin{array}{l}\text {-lacked continuity } \\
\text {-not accept responsibility }\end{array}$ \\
\hline Miguel Fernandez & Manager & Punta Leona & $\begin{array}{l}\text { WSI, WSII, FMLI, } \\
\text { FMLII, BMII }\end{array}$ & $\begin{array}{l}\text {-total support to macaw project } \\
\text { (contributed ideas, employees, } \\
\text { transportation, attend meetings) }\end{array}$ \\
\hline Eugenio Gordienko & Owner & Punta Leona & $\begin{array}{l}\text { WSI, WSII, FMLI, } \\
\text { FMLII, }\end{array}$ & $\begin{array}{l}\text {-key person in region } \\
\text {-political \& economic support to } \\
\text { project since } 1994\end{array}$ \\
\hline Alvaro Gonzalez & Store owner & Tarcoles & $\begin{array}{l}\text { WSI, WSII, FMLI, } \\
\text { FMLII, BMLI }\end{array}$ & $\begin{array}{l}\text {-key conservationist in Tarcoles } \\
\text {-President of Tarcoles Development } \\
\text { Association } \\
\text {-75 years old, failing health }\end{array}$ \\
\hline $\begin{array}{l}\text { Guillermo } \\
\text { Hernandez }\end{array}$ & $\begin{array}{l}\text { Assistant } \\
\text { Manager }\end{array}$ & Punta Leona & $\begin{array}{l}\text { WSI, WSII, FMLI, } \\
\text { FMLII, BMLI, BMLII }\end{array}$ & $\begin{array}{l}\text {-key community figure (QG) } \\
\text {-well organized, great } \\
\text { communicating skills }\end{array}$ \\
\hline Marlene Leon & Housewife & $\begin{array}{l}\text { Quebrada } \\
\text { Ganado }\end{array}$ & $\begin{array}{l}\text { WSI, WSII, FMI, FMLII, } \\
\text { BMLI }\end{array}$ & $\begin{array}{l}\text {-woman leader, outspoken } \\
\text {-hard worker }\end{array}$ \\
\hline Rafa Macana & Landowner & Bijagual & & $\begin{array}{l}\text {-protects macaws on land } \\
\text {-promotes tourism }\end{array}$ \\
\hline Lisbeth Mora & School Director & $\begin{array}{l}\text { Quebrada } \\
\text { Ganado }\end{array}$ & WSII & $\begin{array}{l}\text {-key education figure } \\
\text {-promoted envir. educ courses } \\
\text {-always interested in helping }\end{array}$ \\
\hline Victor Mora & Naturalist & Bijagual & $\begin{array}{l}\text { WSII, FMLI, FMII, } \\
\text { BMLI, BMLII }\end{array}$ & $\begin{array}{l}\text {-key Bijagual conservation figure } \\
\text {-bright, resourceful, organizer } \\
\text {-outspoken, pushes for action }\end{array}$ \\
\hline
\end{tabular}


TABLE 1 (Continued...)

Major stakeholders in Central Pacific Scarlet Macaw conservation, Costa Rica.

\begin{tabular}{|c|c|c|c|c|}
\hline Stakeholders & Occupation & Worksite & Participation & Main Conservation Role \\
\hline Jerimias Sirio & $\begin{array}{l}\text { Ranch } \\
\text { Administrator }\end{array}$ & $\begin{array}{l}\text { Hac. } \\
\text { Quebrada } \\
\text { Bonita }\end{array}$ & & $\begin{array}{l}\text {-key conservation figure on ranch } \\
\text {-protected nesting macaws } \\
\text {-prefers to work alone }\end{array}$ \\
\hline $\begin{array}{l}\text { Humberto } \\
\text { Solorzano }\end{array}$ & Teacher & $\begin{array}{l}\text { Quebrada } \\
\text { Ganado }\end{array}$ & $\begin{array}{l}\text { WSI, WSII, FMI, FMII, } \\
\text { BMLI }\end{array}$ & $\begin{array}{l}\text {-key education figure, teaches } \\
\text { conservation principles } \\
\text {-bright, passionate about macaws }\end{array}$ \\
\hline Hernan Vargas & Ranch owner & $\begin{array}{l}\text { Hac. } \\
\text { Quebrada } \\
\text { Bonita }\end{array}$ & & $\begin{array}{l}\text {-offered ranch for research } \\
\text {-conservation advocate } \\
\text {-allows no poaching on ranch }\end{array}$ \\
\hline Rigoberto Ruiz & Bar tender & Tarcoles & FMII, BMLII & $\begin{array}{l}\text {-President of development assoc. } \\
\text {-not much time, unsure of interest }\end{array}$ \\
\hline $\begin{array}{l}\text { Christopher } \\
\text { Vaughan }\end{array}$ & Scientist & university & $\begin{array}{l}\text { WSI, WSII, FMLI, } \\
\text { FMLII, BMLI, BMLII }\end{array}$ & $\begin{array}{l}\text {-researcher since } 1990 \\
\text {-networks with all stakeholders } \\
\text {-accepted by stakeholders }\end{array}$ \\
\hline $\begin{array}{l}\text { WSI- Attended First Re } \\
\text { WSII- Attended Secon } \\
\text { FMLI- Founding mem } \\
\text { FMLII- Founding mem } \\
\text { BMLI- Board member } \\
\text { BMLII- Board member }\end{array}$ & $\begin{array}{l}\text { nal Workshop on S } \\
\text { egional Workshop } \\
\text { of first LAPPA (Aug } \\
\text { of second LAPPA ( } \\
\text { rst LAPPA } \\
\text { econd LAPPA }\end{array}$ & $\begin{array}{l}\text { rlet Macaw Con } \\
\text { Scarlet Macaw } \\
\text { t 1995) } \\
\text { ne 2000) }\end{array}$ & $\begin{array}{l}\text { rvation (October 1994) } \\
\text { nservation (November } 19\end{array}$ & \\
\hline
\end{tabular}

\section{RESULTS AND DISCUSSION}

This section will be discussed under the following general headings: (a) first workshop, (b) second workshop, and (c) evaluation of the Scarlet Macaw conservation effort (1995-2001).

\section{First Workshop}

\section{Strategy agreed upon in first workshop}

Scarlet Macaw conservation was the general objective. Stopping poaching was the highest ranked (of five) specific objectives centered on general objectives, causes, activities, priorities, and expected results (Table 2). Several of the same priorities were mentioned for different specific objectives such as constructing and mounting artificial nest boxes, conducting environmental education courses at local schools, protecting Scarlet Macaw nests during the nesting season, promoting economic incentives, including training tour guides, making arts and crafts, and having a national Scarlet Macaw fair (Marineros \& Vaughan 1995). I was surprised the group did not rank receiving economic incentives as a major priority. Many of the same expected results were mentioned for different objectives including: counting 20-25 macaw chicks per year, increasing successful legal suits against poachers, and having local communities participate in Scarlet Macaw conservation programs.

\section{Results from workshop and how to measure progress}

The workshop participants understood threats to Scarlet Macaws and had good ideas to resolve them. Many identified problems that appear in the literature (chick exploitation, habitat alteration and local community and authority education)(Collar \& Juniper 1992). Identifying chick poaching as the major threat was consistent with Wright et al. (2001). It was important that hunting and harvesting reproducing adults or introducing diseased birds was not considered or recognized as a threat because this has quickly decimated parrot populations elsewhere (Beissinger \& Bucher 1992, Wiley et al. 1992). Progress was to be measured by achieving expected results during a defined time-frame (Table 2).

\section{Who were the conservation stakeholders?}

Guillermo Hernandez, Miguel Fernandez, Eugenio Gordienko (all from $\mathrm{CPL}$ ) and Humberto Solorzano have been heavily involved in the workshop and macaw conservation 
TABLE 2

Strategies for Scarlet Macaw Conservation in the Central Pacific Region, Costa Rica (1995).

\begin{tabular}{|c|c|c|c|c|}
\hline Objective & Causes & Activities & Priorities & Expected Results \\
\hline $\begin{array}{l}\text { Eliminate chick } \\
\text { poaching }\end{array}$ & $\begin{array}{l}\text {-supply \& demand } \\
\text {-no nest protection } \\
\text {-poachers organized } \\
\text {-authorities assist } \\
\text { poaching } \\
\text {-local poverty } \\
\text {-poaching considered a } \\
\text { "sport" }\end{array}$ & $\begin{array}{l}\text {-protect nests } \\
\text {-use artificial nests } \\
\text {-talk to poachers } \\
\text {-train poachers for other jobs } \\
\text {-train communities to } \\
\text { denounce poaching } \\
\text {-prepare report for judges, } \\
\text { mayors and rural police about } \\
\text { endangered macaws }\end{array}$ & $\begin{array}{l}\text {-protect } 10-15 \text { nests } \\
\text {-mount/protect } 15-20 \\
\text { artificial nests } \\
\text {-prepare report on } \\
\text { status of macaws in } \\
\text { region } \\
\text {-meet with poachers }\end{array}$ & $\begin{array}{l}\text {-count } 20-25 \text { young/year } \\
\text {-increase in poacher } \\
\text { accusations } \\
\text {-observe locals } \\
\text { participating in macaw } \\
\text { protection }\end{array}$ \\
\hline $\begin{array}{l}\text { Educate } \\
\text { locals about } \\
\text { endangered } \\
\text { Scarlet } \\
\text { Macaws }\end{array}$ & $\begin{array}{l}\text {-locals don't accuse } \\
\text { poachers } \\
\text {-no environmental } \\
\text { education programs } \\
\text {-locals lack economic } \\
\text { resources }\end{array}$ & $\begin{array}{l}\text {-macaw \& local community } \\
\text { conservation projects (e.j. } \\
\text { Macaw Festival, arts/crafts) } \\
\text {-organize/implement school } \\
\text { environmental education } \\
\text {-find out locals needs }\end{array}$ & $\begin{array}{l}\text {-Macaw Festival } \\
\text {-environmental } \\
\text { education } \\
\text {-teach procedures to } \\
\text { denounce poachers }\end{array}$ & $\begin{array}{l}\text {-Macaw Festival } \\
\text {-count 20-25 young/year } \\
\text {-increase in poacher } \\
\text { accusations } \\
\text {-environmental education } \\
\text { in } 3 \text { local schools }\end{array}$ \\
\hline $\begin{array}{l}\text { Build } \\
\text { institutional } \\
\text { capacity to } \\
\text { protect Scarlet } \\
\text { Macaw }\end{array}$ & $\begin{array}{l}\text {-no logistical resources } \\
\text { and few trained human } \\
\text { resources } \\
\text {-legislation is not } \\
\text { implemented } \\
\text {-judges and other } \\
\text { authorities unaware of } \\
\text { Scarlet Macaw status }\end{array}$ & $\begin{array}{l}\text {-request that Rural Police } \\
\text { cooperate in protection } \\
\text {-help from detectives to find } \\
\text { poached chicks } \\
\text {-restore credibility to } \\
\text { authorities } \\
\text {-local capacity building } \\
\text {-translate scientific information } \\
\text { to communities, decision } \\
\text { makers }\end{array}$ & $\begin{array}{l}\text {-collaboration from } \\
\text { Rural Police to protect } \\
\text { nests } \\
\text {-detectives find nests } \\
\text {-train authorities in } \\
\text { workshops } \\
\text {-take authorities to visit } \\
\text { macaw nests }\end{array}$ & $\begin{array}{l}\text {-count } 20-25 \text { young/year } \\
\text {-increase in poacher } \\
\text { accusations } \\
\text {-observe locals } \\
\text { participating in macaw } \\
\text { protection } \\
\text { - environmental education } \\
\text { in } 3 \text { local schools }\end{array}$ \\
\hline $\begin{array}{l}\text { Scientific } \\
\text { studies on } \\
\text { macaws } \\
\text { and local } \\
\text { communities }\end{array}$ & $\begin{array}{l}\text {-research is very recent } \\
\text {-results do not reach } \\
\text { communities } \\
\text {-insufficient researchers } \\
\text { exist }\end{array}$ & $\begin{array}{l}\text {-publish \& distribute in simple } \\
\text { language research results } \\
\text {-5-years research macaw plan } \\
\text {-study socio-economics of } \\
\text { region } \\
\text {-form a scientific advisory } \\
\text { committee }\end{array}$ & $\begin{array}{l}\text {-simplify, publish \& } \\
\text { distribute research } \\
\text { results } \\
\text {-5-year macaw research } \\
\text { plan } \\
\text {-regional socio- } \\
\text { economic study }\end{array}$ & $\begin{array}{l}\text {-count } 20-25 \text { young/year } \\
\text {-increase in poacher } \\
\text { accusations } \\
\text {-observe locals } \\
\text { participating in macaw } \\
\text { protection } \\
\text { - environmental education } \\
\text { in } 3 \text { local schools }\end{array}$ \\
\hline $\begin{array}{l}\text { Recover } \\
\text { and protect } \\
\text { habitat }\end{array}$ & $\begin{array}{l}\text {-excessive exotic species } \\
\text { reforestation } \\
\text {-fire out of control } \\
\text {-problems with laws and } \\
\text { their application } \\
\text {-deforestation rampant }\end{array}$ & $\begin{array}{l}\text {-reforest in fence rows, } \\
\text { corridors with native species } \\
\text { macaws use macaws } \\
\text {-determine deforestation rates } \\
\text { and meet with locals to discuss } \\
\text { this } \\
\text {-campaign against fires }\end{array}$ & $\begin{array}{l}\text {-elaborate land use } \\
\text { maps } \\
\text {-reforest in fence rows, } \\
\text { corridors with native } \\
\text { species macaws use } \\
\text { macaws }\end{array}$ & $\begin{array}{l}\text {-elaborate land use maps } \\
\text {-reforest in fence rows, } \\
\text { corridors with native } \\
\text { species macaws use } \\
\text { macaws }\end{array}$ \\
\hline
\end{tabular}

work since 1994. The CPL played an important role by facilitating installations, employees and funds. Because they receive thousands of Costa Rican and foreign visitors yearly and are the largest employer in the region, they established themselves as a major stakeholder in terms of Scarlet Macaw conservation. In addition, the community leaders were outspoken and had a good grasp of the major problems facing macaw conservation. It was obvious that some leaders (Guillermo Hernandez, Victor Mora, and Alvaro Gonzalez) wanted to take action.

The almost total absence of the National Parks Service representative invited comments about their disinterest, corruption and abuse of power among locals. The macaw poachers played a minor role, but provided important information about the number of poachers and poaching techniques. Because they may determine the status of the 
population, they must be taken into account for effective macaw conservation. The university academics chose not to dominate planning and meetings (Barrow \& Murphree 2001). Because it was essential to form an interdisciplinary stakeholder group to tackle the macaw problems, we went out of our way to include park officials in all conservation programs.

\section{How to take actions to achieve conservation goals?}

There was a general anxiety that the strategy would be tabled after the workshop. However, the creation of a local Scarlet Macaw conservation organization was approved by all present and created about 8 months later.

\section{Formation of a local Scarlet Macaw Conservation Organization}

The first workshop recommended the formation of a local watchdog conservation organization. Therefore, LAPPA, "La Asociación para la Protección de los Psitacidos" (see LAPPA 2011), was first created in August 1995. It was created as a civil society as dictated by the Civil Registry in Costa Rica. A general assembly was convened in the elementary school at QG and 23 founding members attended, of whom $50 \%$ were CPL employees, including its owner. There were also land owners, national parks employees, university academics and others. The elected board of directors included a representative from Bijagual, Tarcoles and QG, a national parks employee, and three professionals working in the $\mathrm{CP}$, but living elsewhere (Table 1).

On June 2, 2000, LAPPA was re-inscribed using its old bylaws after failing to report yearly to the Civil Registry. The founders' meeting had 15 members, including 12 past founders. It elected a new board of directors in the general assembly, including leaders from Tarcoles, Bijagual and QG. Roy Arroyo was elected the new President, Guillermo Hernandez and Humberto Solorzano were reelected. A parks service employee, Alvaro Bermudez, was also elected to maintain our contact with them. Evaluating the formation of the Psitacine Protection Association (LAPPA) in 1995 and 2000 was a product of reviewing documents, interviewing board members and reflecting on my personal experiences.

\section{Macaw population increase}

After a decline of $4 \%$ in the August population counts from 1990-1994, a population increase of 37 individuals was noted in the August counts of 37 individuals in two years (1995-1996) and remained constant until 2003 (Vaughan et al. 2005). This was thought a partial result of the work of LAPPA.

\section{Second Workshop}

\section{Strategy agreed upon in Second Workshop}

The mission statement that resulted from this workshop was "to conserve and increase the Cental Pacific Scarlet Macaw population". In addition, the poaching of chicks, lack of education towards the local communities and habitat alteration were considered the most important threats to the population, with poaching twice as threatening as the other two. The conceptual model showed how direct and indirect threats affected Scarlet Macaw conservation (Fig. 1).

In the model, threats affecting Scarlet Macaw hunting (eggs, chicks and adults) and habitat deterioration were traced to land tenure, poor government policy, and culture and education. Each threat was met by a management plan with objectives, activities, timetables and responsible persons (Table 3). Finally, monitoring presented a special challenge to the group. It was discussed, but I had to provide initial insight because most participants were not skilled in this line of thinking. They caught on quickly, however, and formulated monitoring for the last objectives (Table 3 ).

\section{Results from Second Workshop and how to measure progress}

Most participants had attended the 1994 workshop. They still considered the major threat to the macaw population to be chick poaching, followed by lack of education. However, they were able to link direct and indirect threats to management objectives and activities to resolve them. The monitoring programs were a direct form to measure progress towards resolving the threat (Table 3 ).

\section{Macaw population increase}

As noted earlier after the first workshop, after a decline, a population increase of 37 individuals noted in the August counts of 37 individuals in two years (1995-1996) which remained constant until 2003 (Vaughan et al. 2005). This was thought a partial result of the work of LAPPA and the implementation of the recommendations of the 1995 and 1999 workshops.

\section{Who were the conservation stakeholders?}

All participants lived in the region. Most participants lived and/or worked in QG, a kilometer from CPL. The $\mathrm{CPL}$ employees participated in both workshops (the owner and manager the second day) and the resort paid for half of logistical support. Thus QG and CPL were major stakeholders in the workshops. Two schoolteachers who participated were very influential in the successful 


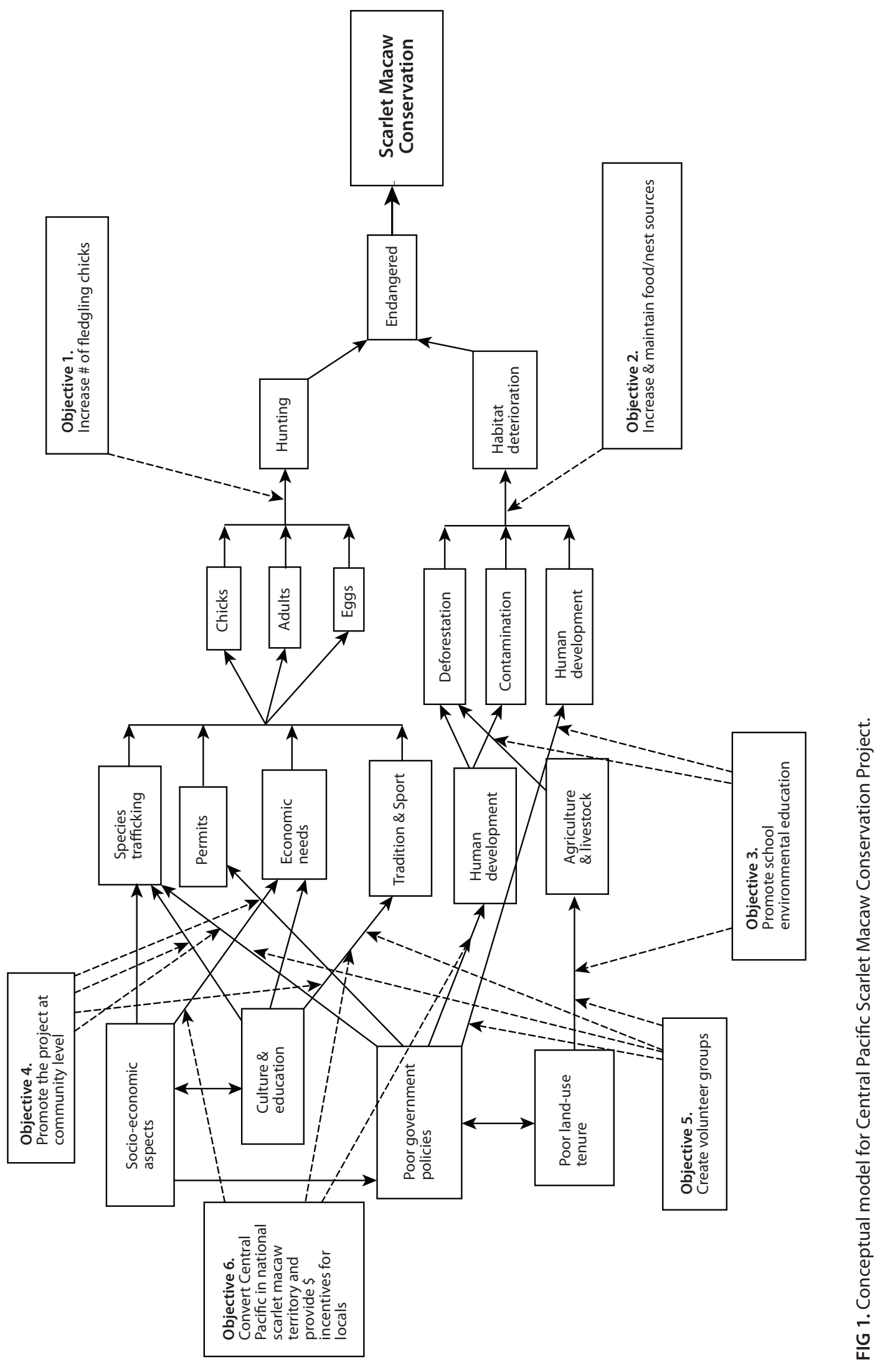


TABLE 3

Management, activities and monitoring for Central Pacific Scarlet Macaw population (November, 1999).

\begin{tabular}{|c|c|c|}
\hline Objectives & Activities & Monitoring (yearly) \\
\hline Stop chick poaching & $\begin{array}{l}\text {-give lectures in schools } \\
\text {-find nests } \\
\text {-construct artificial nest boxes } \\
\text {-concentrate and protect artificial and natural nests }\end{array}$ & $\begin{array}{l}\text {-four lectures/school } \\
\text {-six nests } \\
\text {-10 artificial nest boxes } \\
\text {-in CPL and Hacienda Quebrada Bonita }\end{array}$ \\
\hline $\begin{array}{l}\text { Increase food and } \\
\text { nesting sources }\end{array}$ & $\begin{array}{l}\text {-create three school forestry nurseries } \\
\text {-plant native species in protected areas and near towns } \\
\text {-make a forest inventory to determine food and nesting } \\
\text { sources in Central Pacific } \\
\text {-identify plants in municipal and public areas of interest } \\
\text { for education }\end{array}$ & $\begin{array}{l}-1,000 \text { trees per nursery } \\
-1,000 \text { trees planted } \\
\text {-undetermined } \\
-10 \text { signs per community }\end{array}$ \\
\hline $\begin{array}{l}\text { Continue environmental } \\
\text { education programs }\end{array}$ & $\begin{array}{l}\text {-give short courses in three elementary schools (QG, } \\
\text { Tarcoles, Bijagual) }\end{array}$ & -three shorts courses per school/year \\
\hline Create volunteer groups & $\begin{array}{l}\text {-create groups with public relations and EE committees } \\
\text {-elaborate materials } \\
\text {-provide counsel to organized groups }\end{array}$ & $\begin{array}{l}\text {-committees with } 15 \text { members } \\
\text {-undefined } \\
\text {-undefined }\end{array}$ \\
\hline $\begin{array}{l}\text { Convert SM territory into } \\
\text { tourist destination }\end{array}$ & $\begin{array}{l}\text {-signs about Scarlet Macaw territory along highways and } \\
\text { in towns } \\
\text {-visit businesses requesting donations } \\
\text {-get government decree to declare Central Pacific national } \\
\text { territory of the SM } \\
\text {-promote reports in local newspapers } \\
\text {-create internet pages about SM territory } \\
\text {-ask ICT for participation in tourism fairs } \\
\text {-make brochures about SM }\end{array}$ & $\begin{array}{l}\text {-15 signs } \\
\text {-receive six donations } \\
\text {-decree in one year } \\
\text {-five reports/year } \\
\text {-create internet page } \\
\text {-participate in two fairs } \\
\text {-one brochure }\end{array}$ \\
\hline
\end{tabular}

environmental education programs (Table 1). The $\mathrm{Na}$ tional Parks Service employees attended infrequently, but made excellent contributions.

\section{How to take actions to achieve conservation goals}

The monitoring program was the blueprint to achieve the goals and different persons were responsible for each activity. The Scarlet Macaw conservation organization was to oversee the strategy, which had many aspects similar to the first workshop's strategy.

\section{Comparisons between the First and Second Workshops}

The workshops differed in several ways: a) five years experience in Scarlet Macaw conservation work; b) only locals were involved in the second workshop, c) Lisbeth Mora and Roy Arroyo were new participants and important contributors to the second workshop; and d) Margoluis and Salafsky (1998) provided a much clearer methodology for the participative diagnostic planning process (Table 2, 3 and Fig. 1). The second workshop participants understood the entire design and planning process they were involved in and their responsibilities for actions and 
monitoring of the project. The workshops had the following similarities: (a) they were both carried out in CPL during a 2-day period, (b) both employed a facilitator to help the planning process to develop a strategy, and (c) eight people came to both workshops (Table 1). In addition, the mission and or general objective, threats to the Scarlet Macaw population and many objectives and activities were similar between the two workshops (compare Tables 2 and 3 and Fig. 1). I believe this was attributable to the experience of the participants and the macaw project obtained since the first workshop.

\section{Strategy agreed upon}

The strategy of the first LAPPA board adapted (1995-2000) was based on the first workshop (Table 2). The second LAPPA board adopted the strategy defined in the second workshop (Fig. 1, Table 3). The constitutive act or charter of the second board stated the following objectives: (a) support activities and projects to conserve psitacines (parakeets, parrots and macaws) in Mesoamerica; (b) support ecological studies on psitacines to promote their conservation; (c) help in the restoration of degraded ecological zones which form psitaine habitat; (d) promote socio-cultural and tourist activities that support psitacine and human conservation; (e) support environmental education activities so it creates a consciousness for conserving biodiversity in general and psitacines in particular, (f) seek economic resources to carry out the activities proposed above, $(\mathrm{g})$ seek participation of communities, institutions, municipal governments in activities to conserve psitacines; and (h) provide technical and legal assistence for distinct projects and initiatives (public and private) which relate to psitacines. These were direct reflections of Table 2 and 3.

\section{How to measure progress}

Between 1995 and 1999, the board met at least 12 times to discuss the work plan (Table 2). Different members were assigned activities and progress towards goals was discussed in a general sense. An important index agreed upon by all board members were any changes in the macaw population monitored yearly which continued constant between 1996-2003 (Vaughan et al. 2005). It is necessary to analyze the population data taken between 2003-2012 to see the status of the population presently.

\section{Who were the conservation stakeholders?}

Active members in both boards have included: Guillermo Hernandez, Victor Mora, Humberto Solorzano and Christopher Vaughan. Networking was promoted with: (a)ranchers (Hernan Vargas, Jerimias Sirio, Macana Chaves) who protected artificial and natural macaw nests on their land, (b) schoolteachers who assisted with environmental education courses in different towns (Lisbeth Mora), (c) parks employees for nest protection (Table 1), (d) CPL employees who helped build and mount artificial nest boxes and (e) some parks' employees to help with protection efforts.

\section{How to take actions to achieve conservation goals?}

Several activities from both workshop strategies (Tables 2 and 3) were developed between 1995-2000 by LAPPA board members with mixed results (Table 4).

\section{Evaluation of the Scarlet Macaw conservation effort (1995-2001)}

\section{Time constraints}

Most considered LAPPA had done well with time available, but needed a salaried employee to progress. Board members attended monthly meetings where policy for macaw conservation was discussed. However, because all had full-time jobs, most did not commit to teaching environmental education, protecting chicks, or artificial nest building. Roy Arroyo and Guillermo Hernandez complained they did most of the work. This was in spite of a campaign which had increased LAPPA membership to 75 people (Table 4). When Christopher Vaughan was involved (1990-1997, 2000), he was paid by the university. In addition, they were aware that several of the programs, including environmental education, artificial nest boxes, scientific data collection, and arts and crafts programs had not progressed as much as possible. Nest protection was carried out during Easter Week by volunteers when they had vacation time, but it was insufficient.. They were divided on effectiveness in controlling poaching, most alleging that park guards continued to collaborate with poachers or were indifferent to macaw conservation. Also they concurred that most of the scientific work, environmental education, mounting and monitoring artificial nest boxes had been carried out by Christopher Vaughan and collaborators. I agreed with their evaluation and marvel that Roy Arroyo and Guillermo Hernandez had invested so much time.

\section{Progress on several fronts}

Members of both boards thought the school environmental education programs were very beneficial to the communities and should be expanded (Vaughan et al. 2003a). All concurred the artificial nest box program was beneficial to increase Scarlet Macaw reproduction, educate school children, and facilitate protection (Vaughan et al. 2003b). They were also proud of the internet connection and quarterly bulletin they produced related to LAPPA (http://www.lappacr.org/es/sobre-lappa.php). 
TABLE 4

Activities carried out by LAPPA (1995-2001).

\begin{tabular}{|c|c|c|}
\hline Activity & $\begin{array}{l}\text { Board member responsible } \\
\text { (LAPPA board) }\end{array}$ & Progress \\
\hline Protect nests & $\begin{array}{l}\text { Guillermo (I \& II), Chris (I), } \\
\text { Roy (II) }\end{array}$ & $\begin{array}{l}\text {-very difficult, random distribution in large area } \\
\text {-concentrated natural/artificial nest in three, then one site (Hacienda } \\
\text { Quebrada Bonita) } \\
\text {-park guards uninterested, LAPPA paid guards for two months of 24-hours } \\
\text { periods }\end{array}$ \\
\hline Artificial nest boxes & Chris (I,II) & $\begin{array}{l}\text {-35 financed/built by CPL, mounted by Chris and CPL } \\
\text {-21 chicks fledged from } 5 \text { nests between 1995-2000 } \\
\text {-concentrated with natural nests in three sites (CPL, CNP, Hacienda } \\
\text { Quebrada Bonita) } \\
\text {-best site was Hacienda Quebrada Bonita }\end{array}$ \\
\hline Networking & Guillermo (I \& II), Chris (I) & $\begin{array}{l}\text {-first time communities, ranchers, resorts and park service work together, } \\
\text { relieve much built-up tension } \\
\text {-positive impact on other conservation projects }\end{array}$ \\
\hline $\begin{array}{l}\text { Environmental } \\
\text { education }\end{array}$ & Humberto (I \& II), Chris (I) & $\begin{array}{l}\text {-one course given yearly in elementary schools of Bijagual, Tarcoles and } \\
\text { QG (1995-1999) } \\
\text {-excellent information transfer from students and parents (see article in J. } \\
\text { Environ. Educat) }\end{array}$ \\
\hline Promote arts \& crafts & Guillermo (I \& II) & $\begin{array}{l}\text {-tried teaching wood working using CPL equipment, but failed } \\
\text {-community tourism plans elaborated for four communities with UNA }\end{array}$ \\
\hline Scientific studies & Chris (I \& II) & $\begin{array}{l}\text {-studied ecological aspects of Scarlet Macaw population } \\
\text {-difficult to acquire information from macaws }\end{array}$ \\
\hline Volunteer groups & Roy (II) & $\begin{array}{l}\text {-centerpiece of II board President } \\
\text {-75 volunteers signed up, only } 6 \text { contributed work } \\
\text {-has not show investment worthwhile }\end{array}$ \\
\hline
\end{tabular}

The scientific and monitoring program had been important to track the expansion of the population and all attribute the $6 \%$ increase in the macaw population to their programs (Vaughan et al. 2005). However, they would like a scientist to continue the research that I started in 1990. These local people have embraced the importance of science and monitoring although none were trained in the scientific method. Only one, Humberto Solorzano, is a college graduate. I believe that LAPPA has progressed towards several of its conservation goals, however many were due to my continued presence.

\section{Financial problems}

The LAPPA budget has always been very tight. Since 2000, LAPPA has received funding from diferent conservation organizations. However, financial reports from LAPPA, produced sporadically, showed that received funding was spent in accordance with the second workshop strategy.
In addition, the occasional LAPPA bulletins have been of excellent quality, demonstrating Roy's quality as an editor. CPL has provided a large amount of logistical and material support throughout the history of the project. Board members still consider CPL a major stakeholder in the project. Its economic contributions have maintained the project since the beginning.

\section{CONCLUSIONS}

\section{Strategic planning}

These are the conclusions of this study:

- Strategic planning for a conservation organization is necessary, especially initially. It is also important to measure progress and be adaptive to changing circumstances, threats, funding, actors, and related issues. 
- A strict methodology for conservation planning should be adhered to, such as the Margoluis and Salafsky (1998) planning model.

- There is a need to network and get many actors involved (land owners, teachers, students, park personnel, poachers, resort personnel and owners, community leaders and members, craftsmen, and some academics.

- Advanced planning is needed to ensure a successful meeting. Assume that 50 percent of the invitees won't be able to attend.

\section{Running a conservation project}

- Local community must manage the project. Empowerment with oversight as suggested by Kramer and VanShaik (1997) is recommended. The salaried coordinator must be adaptable to changes, and have good public relations.

- To avoid corruption, accurate and transparent bookkeeping must be accomplished, with periodic audits.

\section{Benefits to local communities}

- The project must benefit the local community if it is to survive. However, many locals and tourists haven't made the connection between community involvement and Scarlet Macaw survival. The new LAPPA web page will increase consciousness about this.

- This project needs the local community to buy into it and to promote ways the local community benefits directly from presence of Scarlet Macaws in the landscape.

\section{Actors in this conservation project}

- We have had continuing difficulty involving parks guards and directors in the project because they have little supervision, few demands and do not feel part of the process. Locals don't trust them because of past encounters and authority abuse. However, they legally manage the natural resources in the area and we have decided to continue to invest in them, hoping that eventually they will come around.

- It is important to have powerful political and economic allies to work with. With this project, CPL has been a major actor since the project began. Without their assistance, this project wouldn't exist.

- Another major actor includes the landowners who protect macaw habitat. Sixty-six percent of nests encountered have been on private lands. We must cultivate good relations with ranchers, such as Hernan Vargas who protects nesting macaws on natural and artificial nest boxes we have placed on his ranch.

\section{Role of science, monitoring and management}

- Certain types of monitoring are very important to measure success of this project. For instance, without monitoring the Scarlet Macaw population, we wouldn't have known if it was declining or increasing, important for judging success or failure of this conservation project with an endangered species (Vaughan et al. 2005).

- Successful high-visibility population, habitat and human management activities are key to perceived project success. Understanding Scarlet Macaw diet (Vaughan et al. 2006) is one area of interest for management purposes.

- Although our artificial nest boxes have met with limited success, it is perceived as very successful by the local, national and international communities (Vaughan et al. 2003b). This brings a positive image to the project. It is important that projects such as the artificial nest boxes are maintained.

- Environmental education (Vaughan et al. 2003a) is a successful management strategy.

\section{Concluding remarks}

- Small victories over time are the key to successful projects. They add up.

- Time is a very important factor to consider when asking locals to buy into a project. Immediate gratification will not occur. Donor agencies must be ready for long-term investments with local community projects in conservation;

- Strategic planning is necessary on a continuous basis, at least yearly.

- The environmental education program is perhaps the most transparent success story of the overall project and should be continued and expanded.

- Local community organizations can manage their own shop, including funds from donors. They must be held accountable as any other organization.

- Research and monitoring are cornerstones to the management and outreach; however they must provide useful information.

- Projects on highly visible endangered species, such as the Scarlet Macaw, should be expanded to other areas of its distribution in Costa Rica, such as the Osa Peninsula. There is a much larger population found there (Dear et al. 2010) 


\section{ACKNOWLEDGEMENTS}

I wish to thank all the stakeholders who have contributed to ensure that the Scarlet Macaws will continue to fly in the Central Pacific. Most are listed in Table 1, but Memo, Hernan, Eugenio, Miguel, Roy, Victor, Alvaro, Lisbeth and Humberto have been involved in this project for several years. Also I am grateful to the Wildlife Trust for funding the project for the last four years and The Parrot Society-UK for funding the publication of this paper. My children: Andres, Catalina, Jessica and Cristina were extremely patient during my research and commitment to the Scarlet Macaws. This paper formed part of my PhD dissertation, presented in The Gaylord Nelson Institue of Environmental Studies at the University of Wisconsin-Madison (Vaughan 2002). I sincerely thank my committee members: Raymond Guries, Timothy Moermond, Robert Ray, Stanley Temple and Thomas Yuill for their unfailing support in my quest to culminate my doctorate.

\section{REFERENCES}

Agrawal, A. \& C. Gibson. 1999. Enchantment and disenchantment: The role of community in natural resource conservation. World Development 27(4):629-649.

Alvarado, C. \& J. Ballestero. 1995. Ostional, Costa Rica: An example of a seas turtle conservation strategy and social welfare. p. 4-7 In J. Bissonette \& P. Krausman (eds). Integrating people and wildlife for a sustainable future. The Wildlife Society. Bethesda, Maryland, USA.

Beissinger, S. \& E. Bucher. 1992. Sustainable harvest of parrots for conservation. p. 73-116 In S. Beissinger \& N. Snyder (eds). New world parrots in crisis: solutions from conservation biology. Smithsonian Institution, Washington, D.C., USA.

Boo, E. 1990. Ecotourism: The potentials and pitfalls. World Wildlife Fund. Washington, D.C., USA.

Brandon, K., K. Redford \& S. Sanderson. 1998. Parks in peril: people, politics and protected areas. Island, Washington, D.C.,USA.

Collar, N. \& A. Juniper. 1992. Dimensions and causes of the parrot conservation crisis. p. 1-24 In S. Beissinger and N. Snyder (eds). New world parrots in crisis: solutions from conservation biology. Smithsonian Institution, Washington, D.C., USA.

Dear, F., C. Vaughan \& A. Morales. 2011. Current status and conservation of the Scarlet Macaw (Ara macao) in the Osa Conservation Area (ACOSA), Costa Rica. Cuadernos de Investigación 2: 3-17

Direccion General de Estadisticos y Censos. 1987. Censo Agropecuario 1984. Ministerio de Economia, Industria y Comercio. San Jose, Costa Rica.
Garcia, R. 1993. El sistema nacional de areas silvestres protegidas de Costa Rica: Un nuevo enfoque. Flora, Fauna y Areas Silvestres 6(15):14-18

Ghai, D. 1994. Development and environment: Sustaining people and nature. Special Issue. Development and Change 24.

Ghai, D. \& J. Vivian. 1992. Grassroots environmental action: People's participation in sustainable development. Routledge for UNRISD. London, United Kingdom

Hernandez, L. 1993. La extension y la educacion ambiental en el manejo del venado colablanca en Cobano, provincial de Puntarenas, Costa Rica. p. 359-368 In C. Vaughan \& M. Rodriguez (eds). Ecologia y Manejo del Venado Colablanca en Mexico y Costa Rica. Universidad Nacional, Heredia, Costa Rica

Hulme, D. \& M.Murphree. 2001a. African wildlife and livelihoods: the promise and performance of community conservation. James Currey Ltd. Oxford, United Kingdom.

Hulme, D. \& M.Murphree. 2001b. Community conservation as policy: promise and performance. p 281-297 In D. Hulme and M.Murphree (eds). African wildlife and livelihoods: the Promise and performance of community conservation. James Currey Ltd. Oxford, United Kingdom.

Kramer, R. \& C. VanSchaik. 1997. Preservation paradigms and tropical rain forests. p. 3-10. In R. Kramer, C. VanSchaik and J. Johnson (eds). Last stand: protected areas and the defense of tropical biodiversity. Oxford University, New York, New York, USA

LAPPA, 2011. La Asociación para la Protección de Psittacidoshttp (Disponible en : www.lappacr.org/es/links.php Consultado el 31 de enero de 2012)

Leach, M., R. Mearns, \& I. Scoones. 1999. Environmental entitlements: dynamics and institutions in community-based natural resource management. World Development 27:225-247.

Margoluis, R. \& N. Salafsky. 1998. Measures of success: designing, managing and monitoring conservation and development projects. Island, Washington, D.C., USA.

Marineros, L. \& C. Vaughan. 1995. Scarlet Macaws of Carara. p. 445-468. In J. Abramson, B. Speer \& J. Thomsen (eds). The large macaws: their care, breeding and conservation. Raintree, Fort Bragg, California, USA.

Nichter, M. 1984. Project community diagnosis: Participatory research as a first step toward community involvement in primary health care. Social Science \& Medicine 19: 237-252

Salafsky, N., R. Margoluis, K. Redford \& J. Robinson. 2002. Inedited. Improving the practice of conservation: a conceptual framework and agenda for conservation science.

Stiles, G. \& A. Skutch. 1989. Birds of Costa Rica. Cornell University, Ithaca, New York, USA

Umaña, A. \& K. Brandon. 1992. Inventing institutions for conservation in Central America: lessons from Costa Rica. p. 85106 In S. Annis (ed). Poverty, natural resources and public 
policy in Central America. Transaction, New Brunswick, New Jersey, USA.

Vargas, G. 1992. Cartografia, fitogeografia de la Reserva Biologica de Carara. San Jose: Universidad de Costa Rica, San Pedro, Costa Rica.

Vaughan, C. 1999. Do local communities in developing countries benefit from ecotourism in national parks and protected areas? Vida Silvestre Neotropical 8: 3-9.

Vaughan, C. 2002. Conservation strategies for a Scarlet Macaw (Ara macao) population in Costa Rica. PhD disseration, University of Wisconsin, Madison.

Vaughan, C. 2011. Change in dense forest habitat for endangered wildlife species in Costa Rica from 1940 to 1977. Cuadernos de Investigación 3: 15-77.

Vaughan, C. \& J. Liske. 1991. Ecotourism and the Scarlet Macaw (Ara macao) population at Carara Biological Reserve, Costa Rica: A case for commensalism? p. 35-39 In J. Clinton-Eitniear (ed). Proceedings of the first Mesoamerican workshop on the conservation and management of macaws. Center for the Study of Tropical Birds, Austin, TX, USA.

Vaughan, C. \& C. Rodriguez. 1997. Managing beyond the borders: The Costa Rican national system of conservation areas (SINAC). p. 441-451 In G. Meffe \& C. Carroll (eds). Principles of Conservation Biology. Sinauer Associates, Sunderland, Massachusetts, USA.

Vaughan, C., J. Gack, H. Solorzano \& R. Ray. 2003a. The effect of environmental education on school children, their parents and community members: A study of intergenerational and intercommunity learning. Journal of Environmental Education.34: 12-21

Vaughan, C., N. Nemeth \& L. Marineros. 2003b. Ecology and management of natural and artificial Scarlet Macaw (Ara macao) nest cavities in Costa Rica. Ornitología Neotropical. 14: 381-396
Vaughan, C., N. Nemeth, J. Cary \& S. Temple. 2005. Response of a Scarlet Macaw (Ara macao) population to conservation measures. Birdlife International 15: 119-130

Vaughan, C., N. Nemeth \& L. Marineros. 2006. Observations of Scarlet Macaw (Ara macao) diet in Central Pacific Costa Rica. International Journal of Tropical Biology and Conservation 54: 919-926.

Wells, M. 1994. Biodiversity conservation and local development aspirations: New priorities for the 1990s. p. 306320 In C. Perrings, K. Maler and C. Holling (eds). Biodiversity conservation: problems and policies. Kluwer, Amsterdam, Holland

Wells, M. \& K. Brandon. 1992. People and parks: linking protected area management with local communities. The World Bank. Washington, D.C., USA

Western, D. \& R. Wright. 1994. The background to communitybased conservation. p. 1-12. In D. Western, M. Wright \& S. Strum (eds). Natural connections: perspectives in community-based conservation. Island, Washington, D.C., USA

Wiley, J., N. Snyder \& R. Gnam. 1992. Reintroduction as a conservation strategy for parrots. p. 165-200. In S. Beissinger and N. Snyder (eds). New world parrots in crisis: solutions from conservation biology. Smithsonian Institution, Washington, D.C, USA

Wright, T., Toft, C., Enkerlin-Hoeflich, E., Gonzalez-Elizondo, J., Albornoz, M., Rodriguez-Ferraro, A., Rojas-Suarez, F., Sanz, V., Trujillo, A., Beissinger, S., Berovides, V., Galvez, X., Brice, A., Joyner, K., Eberhard, J., Gilardi, J., Koenig, S., Stoleson, S., Martuscelli, P., Meyers, J., Renton, K., Rodriguez, A., Sosa-Asanza, A., Villela, F., \& Wiley, J. 2001. Nest poaching in Neotropical parrots. Conservation Biology 15: 710-720

World Conservation Monitoring Center. 1992. Global biodiversity: status of the Earth's living resources. Chapman and Hall. London, United Kingdom. 